\title{
KUŹNIA HEFAJSTOSA CZYLI KRÓTKI ZARYS TEORII WIZERUNKU W KOMUNIKACJI CZLOWIEKA
}

\author{
STANISŁAW PUPPEL
}

Our fate is in the 'hands' of the image. We live in an ever changing world of performing images.

\section{Uwagi wstępne}

Wizerunek stanowi nieodłączną część wszelkiej ziemskiej cielesności (bytowości fizycznej/organizmalnej). Jako fizyczność jest ona jednocześnie obdarzona własnością niejako janusowej 'aparycji', tj. zarówno 'wyglądem' jak i 'oglądem', a więc wyposażeniem jej w różnorakie atrybuty nadawczo-odbiorcze, i - co się z tym wiąże - nieuniknioną koniecznością wysyłania wyglądu na zewnątrz (tj. ruchu od danej cielesności ku innym cielesnościom) a także nieuniknioną koniecznością odbierania wyglądu (czyli oglądu) przez inne cielesności (tj. ruchu ku danej cielesności), tj. postrzegania jej przez inne cielesności właśnie poprzez odwołanie się do tychże atrybutów. Wizerunek (łac. imago, ang. visage, image) jako złożone zjawisko o charakterze z zasady semiotycznie izomorficznym (tj. zakładające zgodność wizerunku $\mathrm{z}$ danym obiektem) stanowi więc jeden $\mathrm{z}$ fundamentalnych warunków istnienia wszelkich bytów w wymiarze 'cielesno-kohabitacyjnym' (a więc w wielkim układzie życia zorganizowanym m.in. wokół ontologicznej i stereoskopowej zasady 'mam ciało, nie jestem sam/a, tym samym zawsze mam wygląd i zawsze podlegam oglądowi', zob. w sprawie stereoskopowej diady wyglądu-oglądu (ang. etic-emic), zob. Pike, 1957; 1967), regulowania ruchów między nimi, automatycznej wymiany wizerunków, i w konsekwencji zachowywania bądź określonej cielesnej, w tym 
wizerunkowej równowagi, bądź jej zaburzania w całokształcie ogromnej różnorodności form biotycznych (biosu) występujących w biosferze. Powiedzielibyśmy zatem zaraz na początku niniejszego eseju, że wizerunkowość podlega, jak w przypadku powszechnego prawa ciążenia, 'prawu powszechności wizerunku', któremu to prawu podlegają wszystkie cielesności ziemskie. Możemy więc wręcz mówić o swoistym Dictatus imaginis 'globalnego układu wizerunkowego', w którym zanurzony jest ziemski bios.

Stąd istotnym jest nieustanne podejmowanie w sposób zupełnie naturalny przez różne gatunki biologiczne wszelakich wysiłków w celu wytwarzania i utrzymywania wizerunku korzystnego dla siebie, tj. zarówno gatunkowo jak i w wymiarze indywidualnym za pomocą określonych środków (zasobów) pozostających do dyspozycji tychże gatunków. Wiemy na przykład o niezwykle ważnej roli barw, zapachów, kształtów a także szeroko pojętej kinetyki w świecie roślin, owadów i zwierząt. Mają one wartość podstawową dla utrzymania przy życiu różnych gatunków zarówno poprzez odstraszanie potencjalnych wrogów jak i przyciąganie potencjalnych sojuszników ('aliantów', jak byśmy powiedzieli, np. partnerów seksualnych, wszelkich symbiontów, etc., zob. np. Poulton, 1890; Attenborough, 1995; Komárek, 2003; Ruxton et al., 2004; Siebeck, 2004; Speed et al., 2010; Chittka et al., 2014).

Zatem wizerunek, jego wytwarzanie, posiadanie i utrzymywanie (tj. skupianie się na nim i nieustanne pielęgnowanie go) zarówno w wymiarze gatunkowym jak i indywidualnym stanowią istotne elementy dynamiki życia. Stanowią także treść swoistej uniwersalnej 'psychologii wyglądu-oglądu' (zob. np. Merleau-Ponty, 1945/ /1962; Guilford i Dawkins, 1993), a więc wymiaru głębokiego towarzyszącego podstawowemu ogniwu wszelkiej kohabitacji biologicznej rozgrywającej się na fundamentalnej osi ‘ja - ten inny' i wyrażonej według następujących zasad:

- 'jako cielesność zawsze mam jakiś wygląd i zawsze jest jakiś jego ogląd',

- 'wszystko w cielesności tworzy wizerunek tejże cielesności'.

Zasady powyższe można określić jako stanowiące część głębokiego przypasowania wszelkich bytów biologicznych nośnikowi ziemskiemu i wszystkiemu, co się na nim znajduje. Doskonale oddaje to przypasowanie wprowadzony przez Jakoba von Uexkülla termin Umwelt (zob. np. Uexküll, 1909; 1926; 2010). Termin ten jednocześnie w pełni uzasadnia stanowisko, zgodnie z którym wizerunek zawarty jest zarówno w wymiarze biologicznym jak i u człowieka, w antroposferze, w wymiarze czysto społeczno-kulturowym. Dualizm ten, wyrażony w wizerunku biologicznym i wizerunku społeczno-kulturowym, przyjęty został w niniejszym opracowaniu za podstawowy.

W tym kontekście niech za prostą i klasyczną zarazem ilustrację 'psychologii wyglądu-oglądu' w otoczce kulturowej człowieka posłuży obrazek przedstawiający złą królową przeglądającą się w lustrze w nieśmiertelnej bajce braci Grimm pt. Królewna śnieżka (2008). Jest ona wręcz znakomitą ilustracją zjawiska wizerunkowości. 


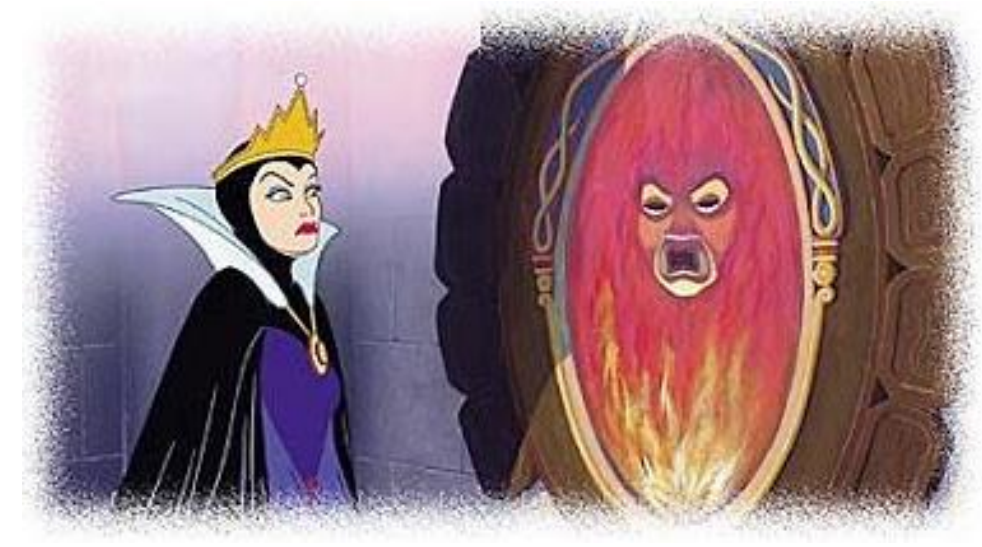

Rys. nr 1

Wizerunek możemy rozumieć w dwojaki sposób, a więc przede wszystkim:

(a) statycznie, tj. jako posiadanie przez daną 'cielesność' (tj. fenomenologicznie czyli jako organizm biologiczny lub kulturowo-instytucjonalny) większej lub mniejszej świadomości odnośnie własnej tożsamości, tj. określonego stanu tejże cielesności ( $\mathrm{tj}$. organizmu biologicznego lub tworu kulturowo-instytucjonalnego, zob. delficka maksyma gnōthi seauton, łac. nosce te ipsum, ang. know thyself, 'poznaj samego siebie') koniecznie w układzie przestrzenno-kohabitacyjnym, tj. vis-a-vis innych cielesności interagujących z sobą, czyli współpracujących lub konkurujących z sobą w wszechobejmującej przestrzeni i arenie życia. Statyczność wizerunku rozumieć można także jako jego strukturę różnicującą poszczególne wizerunki (ang. structure, design, zob. np. Deleuze, 1994; Lidwell et al., 2003)

(b) dynamicznie, $\mathrm{tj}$. jako dynamizm polegający na nieustannym podejmowaniu przez daną cielesność różnych działań interakcyjno-komunikacyjnych polegających na nieustannym wytwarzaniu wizerunku, czyli wytwarzaniu u odbiorcy (a więc u 'tego innego') określonych wrażeń mających na celu ochronę danej cielesności czy okazanie dbałości o indywidualną bądź zbiorową estetykę wizerunku, określaną terminem 'piękniej', czy to poprzez mniej lub bardziej kosztowne (tzw. 'uczciwe sygnalizowanie' siebie, ang. honest signalling, costly signalling) czy też 'sygnalizowanie zwodnicze', a więc o charakterze oszukańczym i nieuczciwym (ang. dishonest signalling, zob. w tej sprawie np. Zahavi, 1975; Zahavi, 1977; Ekman, 1997; Zahavi, 1997; Archetti, 2000; Gintis et al., 2001; Archetti i Brown, 2004; Maynard Smith i Harper, 2003; Searcy i Nowicki, 2005; Pentland, 2008). Dynamiczność wizerunku można rozumieć także jako jego 'adaptacyjny potencjał retoryczny’ dający się realizować w określonych porządkach komu- 
nikacyjnych, np. w porządku wokalno-słuchowym, graficznym czy hybrydowym (zob. Puppel, 2015) dla opisanych powyżej celów perswazyjnych (zob. np. Parrish, 2014) poprzez wizerunkowe działania 'repetycyjne' (zob. np. Deleuze, 1994).

Całokształt wszystkich cech zarówno stanu wizerunku jak i działań wizerunkowych możemy określić wspólnym mianem 'pokazu' (ang. display) (zob. Puppel, 2009). W niniejszym opracowaniu termin 'pokaz' stosowany będzie zamiennie z pojęciem 'wizerunku' jako w szczególności oddzielny obiekt badań komunikologii, a ściślej jako obiekt badań teorii sygnalizowania (zob. np. Connelly et al., 2011).

Idąc zatem śladem tak zasygnalizowanej ogromnej roli wizerunku wynikającej z powszechnej i niezbywalnej jego obecności w biologicznym świecie zarówno przedludzkim (np. roślinnym, zwierzęcym), protoludzkim jak i w pełni ludzkim, w niniejszym opracowaniu podniesione zostanie zagadnienie ogólnej celowości świadomego budowania, posiadania, utrzymywania i podaży ( $\mathrm{tj}$. rozpowszechniania) odpowiedniego wizerunku przez człowieka w kontekście jego zachowań komunikacyjnych. Jest bowiem rzeczą oczywistą, że w szczególności do człowieka jako niezwykle ważnego elementu składowego biosfery i centralnego składnika antroposfery daje się w pełni zastosować pojęcie wizerunku/pokazu w rozumieniu zarówno jego stanu jak i dynamizmu w szerszym kontekście społeczno-kulturowym, wyrażonym w prostej i powszechnie znanej maksymie „żyj i daj żyć innym” (ang. live and let live), tutaj jednak rozszerzonej do możliwości odniesienia sukcesu wizerunkowego przez człowieka jako transkomunikatora $\mathrm{w}$ kontekście jego występowania w różnych porządkach komunikacyjnych, etnicznościach, kulturach lokalnych i wspólnotach językowo-komunikacyjnych (zob. Puppel, 2015). Sukces ten najlepiej da się wyrazić jako osiągnięcie przez danego transkomunikatora określonej 'atrakcyjności wizerunkowej', która jednocześnie bierze udział w ogólnym generowaniu arystotelesowskiej 'eudajmonii' ('dobrobytu/dobrostanu', ang. well being, prosperity) człowieka jako gatunku i jego poszczególnych przedstawicieli (zob. np. Des Gasper, 2004; Gallagher et al., 2011).

\section{Wizerunek czlowieka jako stan: statyka wizerunku (własnego)}

W rozumieniu statycznym wizerunek można określić zarówno jako: (a) świadomość posiadania przez każdego człowieka określonego wizerunku wewnętrznego (tzw. 'mniemania o sobie'), a więc immanentnego obrazu siebie, oraz jako: (b) świadomość konieczności i umiejętności wywoływania odpowiedniego wrażenia, które ów obraz wywołuje u innych użytkowników otwartej przestrzeni publicznej. Ponadto wszechobejmujący stan 'świadomości wyglądu - wrażenia w oglądzie', w którym 
nieustannie przebywamy, jest jak już zauważono powyżej, istotnie stanem nieuniknionym i nieusuwalnym, a więc stanem towarzyszącym każdemu $\mathrm{z}$ nas $\mathrm{w}$ naszej codziennej egzystencji, noszonym i przenoszonym przez nas, gdziekolwiek się udajemy w otwartej przestrzeni życiowej, w tym w każdym punkcie topologicznie i interakcyjnie rozumianej przestrzeni publicznej. Stan ten niewątpliwie wpływa na nas, często w sposób nieuświadamiany, na nasze odniesienia do przedstawicieli świata istot przedludzkich a także i innych ludzi oraz na naszą działalność, w tym w szczególności na nasze międzyosobowe praktyki komunikacyjne (takie jak np. praktyki altruistyczne, zob. np. Trivers, 1971); Van Lange i Semin-Goosens, 1998), ich jakość, częstotliwość i intensywność (zob. np. Baron-Cohen et al., 1993/2013; Reddy et al., 2010; Zahavi, 2014), mające bezpośredni związek z naszą indywidualną i gatunkową wizerunkowością.

Wizerunek własny jako statyczną strukturę samoprezentacji (ang. self-representation) można przedstawić za pomocą diagramu obejmującego współistnienie i współdziałanie następujących głównych cech ontologiczno-konstrukcyjnych:

1. świadomość transkomunikatora odnośnie ważności/istotności wizerunku własnego (zwana dalej ważnością, W)

2. uczucia towarzyszące wizerunkowi własnemu (zwane dalej uczuciami, U)

3. własny osąd posiadanego przez danego transkomunikatora wizerunku (zwany dalej osądem, Os)

4. własny wewnętrzny obraz wizerunku (zwany dalej obrazem, Ob.; zob. Mondzain, 2004).

Całość nazwać możemy 'kompleksem wizerunkowym człowieka W-U-Os-Ob’.

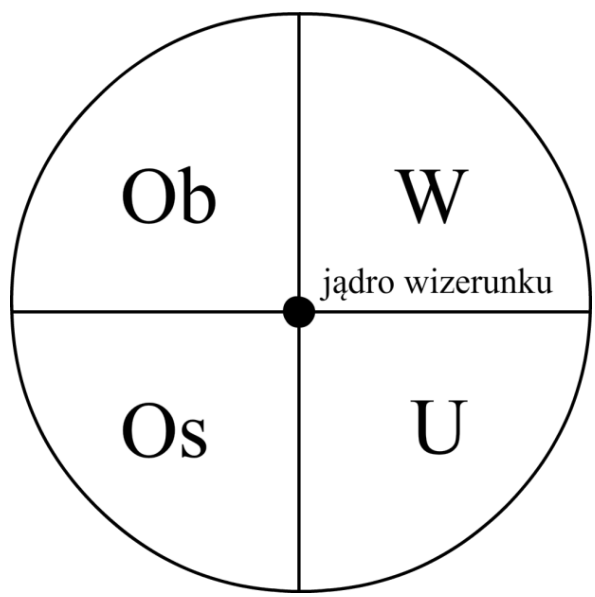

Diagram nr 1. Główne cechy ontologiczno-konstrukcyjne wizerunku własnego obecne w kompleksie wizerunkowym człowieka W-U-Os-Ob (gdzie ciemny punkt w centrum diagramu przedstawia jądro wizerunku człowieka jako synergię cech ontologiczno-konstrukcyjnych wizerunku) 


\section{Wizerunek obiektu/cielesności (także człowieka) jako dynamizm: dynamika wizerunku (własnego)}

Z kolei w rozumieniu dynamicznym wizerunek w odniesieniu do człowieka można określić jako posiadanie przez każdego człowieka świadomości odnośnie możliwości wykonywania określonych działań w zakresie wytwarzania, tj. kształtowania i podaży własnego (tj. zindywidualizowanego) kompleksu wizerunkowego $\mathrm{W}-\mathrm{U}-\mathrm{Os}-\mathrm{Ob}$ w celu dokonywania ciągłych zmian (korekt) w wizerunku przez siebie posiadanym i jednoczesnego zabezpieczania pozytywnego oglądu przez innych. Działania te stanowią niezwykłe bogactwo środków, do których człowiek ma dostęp jako cielesność czysto biologiczna i jako byt społeczno-kulturowy i które to środki może stosować w obrębie poszczególnych cech ontologiczno-konstrukcyjnych przedstawionego powyżej kompleksu wizerunkowego, realizowanego w ramach obustronnie korzystnego mechanizmu wizerunkowej konfiguracji generującego relacje wybranych cech ontologiczno-konstrukcyjnych na osi 'wygląd - ogląd' (ang. win-win relationship).

Należy w tym miejscu podkreślić więc, że wszystkie te działania spróbować można określić za pomocą mechanizmu generatywnego, tj. stosowania pewnego ograniczonego zasobu (tj. zestawu) niezmiennych reguł pozwalających każdemu człowiekowi na wykonywanie tychże działań, w szczególności nieustannego reprodukowania określonego wizerunku (zob. np. Deleuze, 1994; Benjamins, 2008) co można tutaj zbiorczo określić mianem 'dynamiki strategii wizerunkowych' człowieka opartej na poczuciu 'komfortu wizerunkowego' i jego poszczególnych odmian (np. komfortu wizualnego, komfortu fonicznego, komfortu ruchowego czy też nawet komfortu zapachowego).

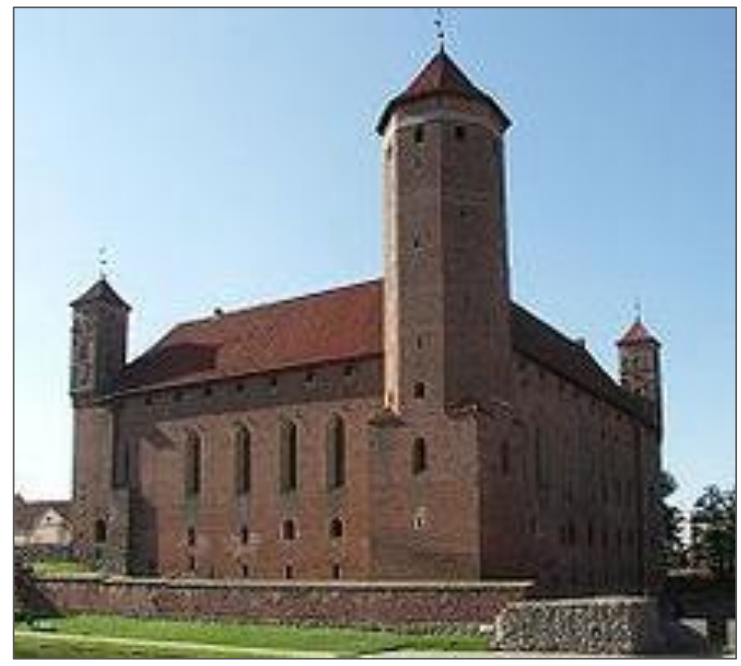

Rys. nr 2. Średniowieczny zamek jako przykład całościowej bryły architektonicznej (wizerunek całości, ze zbioru w posiadaniu autora) 
Strategie te należą z kolei do szerszej kategorii obejmującej pojęcie 'architektury wizerunku' opartej z kolei na pojęciu 'struktury/układu' (zob. np. Steadman, 2008). Może ona mieć charakter zarówno monolityczny, pozwalający na utrzymywanie wyglądu o charakterze całościowym (holistycznym) jak i charakter fragmentaryczny i rozproszony, zatem z konieczności wybiórczy, tj. skupiony na utrzymaniu wyglądu poszczególnych elementów tejże architektury. Całościową architekturę wizerunku można przedstawić najlepiej za pomocą obrazu bryły budynku jako całości (Rys. nr 2).

Natomiast architekturę wizerunku o charakterze wybiórczo-rozproszonym można przedstawić za pomocą obrazu fragmentu budynku, np. wnętrza świątyni, co przedstawia zdjęcie poniżej (Rys. nr 3):

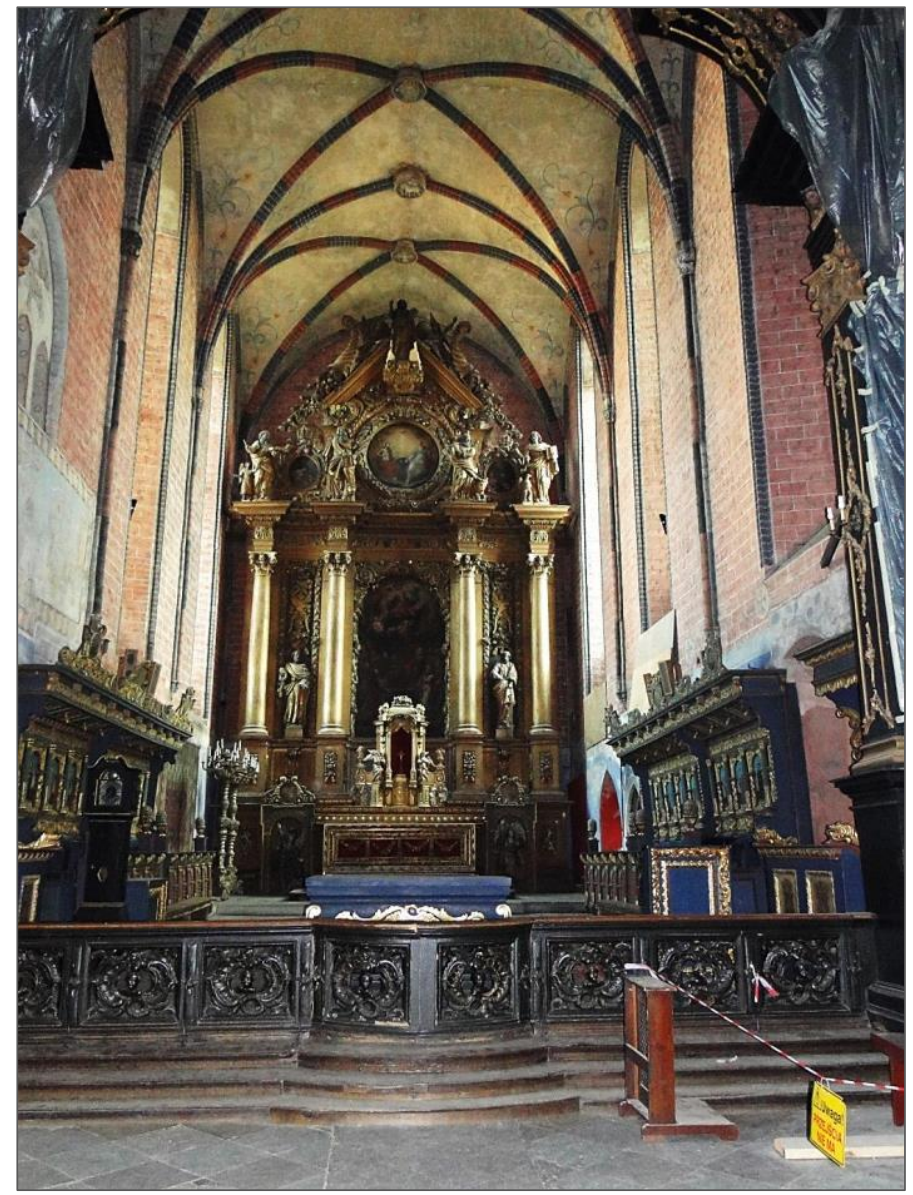

Rys. nr 3. Fotografia wnętrza budynku (tutaj świątyni, gdzie nacisk położony jest na ołtarz jako wybrany fragment wizerunku całokształtu świątyni, ze zbioru w posiadaniu autora) 
Można zatem wyobrazić sobie, że wszelkie działania wizerunkowe człowieka realizowane w ramach strategii wizerunkowych mogą przebiegać dwukierunkowo, a więc albo od całości ku poszczególnym elementom składowym wizerunku, albo od elementów składowych (szczegółów) ku całości. Obydwa typy działalności wizerunkowej doskonale mieszczą się, na przykład, w działaniach architekta tworzącego projekt budowli, w którym to projekcie uwzględnia on zarówno jej strukturalną całość jak i najmniejsze detale danej budowli. Takim architektem (a więc swoistym inżynierem językowym czy wręcz 'kowalem' bądź 'ogrodnikiem' wizerunku) może być także każdy transkomunikator podejmujący określone działania o charakterze językowo-komunikacyjnym w celu wytworzenia (bądź wypielęgnowania) mniej lub bardziej uświadomionego przez siebie (tj. emicznego) wizerunku własnej osoby w przestrzeni publicznej. $\mathrm{W}$ tym sensie każdy transkomunikator bierze udział $\mathrm{w}$ swoistej produkcji przestrzeni publicznej, jak byśmy powtórzyli za Lefebvre, swoistej 'przestrzennej architektoniki' (ang. spatial architectonics, zob. Lefebvre, 1991) nasyconej wizerunkowością.

Zatem metafora 'architekta-kowala' będzie stosowana w niniejszym opracowaniu w pełni świadomie, bowiem każdy z nas jest jako transkomunikator niejako architektem i kowalem własnej wizerunkowości, osiąganej za pomocą dynamiki odpowiednio skoordynowanych strategii wizerunkowych rozumianych jako strategie wytwarzania i podaży wizerunku człowieka skierowanego ku innym uczestnikom przestrzeni publicznej (zob. np. Li i Wang, 2007; Dyer, 2010) celem wywołania u nich określonego oglądu.

Można w konsekwencji założyć, że wszelkie działania wizerunkowe powinny dodatkowo charakteryzować się wysokim stopniem 'skuteczności wizerunkowej' (np. skutecznej wykonawczości i w konsekwencji skuteczności wpływania na inne osoby (znanej jako perswazyjność) dokonujące oglądu, co dobrze oddaje angielski zbiorczy termin high performance, w kwestii wykonawczości w obrębie tzw. 'uniwersalnego mechanizmu wykonawczego', zob. Puppel, w druku) tak, by nieuniknione umieszczenie danego człowieka na osi 'wygląd - ogląd' było dla niego jak najkorzystniejsze. Poniżej przedstawione są niektóre strategie wizerunkowe stosowane przez człowieka.

\section{Strategie wizerunkowe czlowieka}

Wśród strategii wizerunkowych stosowanych przez człowieka jako architekta własnej wizerunkowości w obrębie wymienionego powyżej kompleksu wizerunkowego W-U-Os-Ob wyróżnić można przede wszystkim strategie związane z używaniem dostępnych człowiekowi modalności zmysłowych. Nazywane będą one tutaj 'wizerunkowymi strategiami modalnościowymi' (wsm).

Wyróżnić możemy następujące wizerunkowe strategie modalnościowe:

(a) wizualne strategie mono-modalnościowe (wsmm) (tj. strategie oparte na użyciu jednej z dwóch głównych modalności zmysłowych człowieka używanych w zachowaniach komunikacyjnych, np. najważniejszej modalności 
słuchowo-wokalnej lub modalności wzrokowo-dotykowej czy też w mniejszym stopniu modalności węchowej),

(b) wizualne strategie bi-modalnościowe (wsbm) (tj. strategie oparte na zintegrowanych działaniach dwu-modalnościowych, głównie w zakresie modalności słuchowo-wokalnej używanej jednocześnie/wspólnie z modalnością wzrokowo-dotykową),

(c) wizualne strategie hybrydowe (wsh) (tj. strategie oparte na wykorzystaniu wszystkich możliwych i dostępnych człowiekowi modalności sensorycznych z użyciem nośników technologicznych). W takim przypadku możemy mówić o działaniu całościowego 'agregatu strategii wizerunkowych' obejmującego naturalną diadę 'ucho-oko'.

Z kolei wymieniona powyżej cielesność (tj. zarówno organizm biologiczny jak i kulturowo-instytucjonalny) jako podstawowa domena/obiekt działalności wizerunkowej w węższym odniesieniu do człowieka rozumiana może być w dwojaki sposób związany z pojęciem 'postaciowości' ludzkiej (p) jako podstawowym wyrazem cielesności, a więc w następujących wymiarach:

- jako cała postać (cp) (zob. np. bryła zamku przedstawiona powyżej, która także podlega wymiarowi cp,). (o 'całej postaci' jako kluczowym pojęciu 'psychologii postaci' zob. np. Ash, 1995),

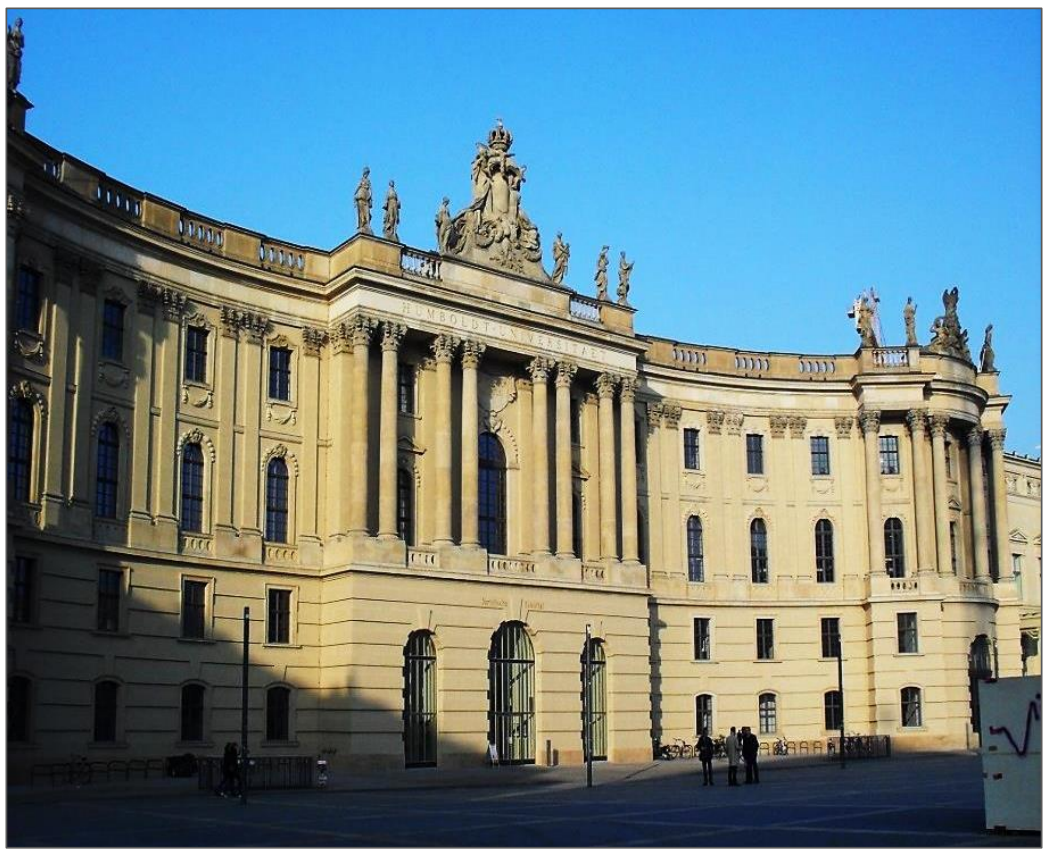

Rys. nr 4. Architektura budynku (nacisk na wizerunek fasady - fasada postaci, ze zbioru w posiadaniu autora) 
- jako fasada postaci (fp) (co ilustruje rys. zamieszczony poniżej, Rys. nr 4. Także i on podlega wymiarowi fp). $\mathrm{O}$ fasadzie, zwłaszcza niezwykle istotnej dla wizerunku tzw. 'radosnej fasadzie', możemy mówić jako obiektywizacji ważności przodu postaci (ang. cheerful façade), zob. Bloch, 2006, także Leatherbarrow, 1985) czy też o 'fasadzie o wysokiej efektywności' (ang. high performance façade), o której możemy mówić w sensie jej skuteczności wizerunkowej.

Możemy więc w odniesieniu do człowieka odpowiednio mówić o przynajmniej dwóch głównych strategiach wizerunkowych związanych z powyższym podziałem:

(1) 'strategii wizerunku całej postaci' (swcp), która bierze pod uwagę całość danej postaci (osoby, figury/bryły, instytucji), oraz

(2) 'strategii wizerunku fasady postaci' (swfp), która skupia się wyłącznie na centralnym fragmencie postaci, tj. fasadzie domeny/obiektu (np. osoby, figury/bryły, instytucji). Strategie te nazwiemy tutaj odpowiednio 'strategiami postaciowymi'. Obydwie strategie dają się z kolei podporządkować strategiom mono-modalnościowym, bi-modalnościowym oraz $\mathrm{w}$ pełni hybrydowym, o których była mowa powyżej. Tak więc możemy w tym momencie zaproponować następujący ogólny 'wzorzec kombinacyjny strategii wizerunkowych' stosowanych przez człowieka, gdzie działanie kompleksu wizerunkowego człowieka jest wynikiem synergii całej postaci i fasady:

\begin{tabular}{c|c} 
cała postać & fasada \\
\hline wsmm + swcp & wsmm + swfp \\
wsbm + swcp & wsbm + swfp \\
wsh + swcp & wsh + swfp
\end{tabular}

Diagram nr 2. kompleks wizerunkowy człowieka W-U-Os-Ob

$\mathrm{Z}$ czysto formalnego punktu widzenia podkreślić należy, że własny kompleks wizerunkowy człowieka (a więc odczuwany wewnętrznie. tj. 'wyglądowy' i generowany przez poczucie komfortu wizerunkowego) można najpełniej zrealizować łącząc odpowiednio strategie modalnościowe ze strategiami postaciowymi. W ten sposób dana 'jednostka wizerunkowa' (ang. entity, np. człowiek, instytucja, etc.) może zabezpieczyć sobie możliwość generowania odpowiednio zintegrowanego i pozytywnego (w tym także estetycznego) wizerunku (zob. Puppel, 2012; 2014), co każe nam z kolei rozważyć zagadnienie stosowania zasad polityki i ekonomii w tworzeniu i podaży wizerunku.

\section{Polityka wizerunku}

Prawo powszechności wizerunku zakłada, że wszelkie byty posiadają wizerunkowość rozumianą jako podlegającą 'wyglądowi-oglądowi', co opisano powyżej. Skuteczność w zakresie działalności wizerunkowej każdej jednostki wizerunkowej 
wynika z kolei ze stosowania przez owe jednostki 'polityki wizerunku'. Ma ona dwa podstawowe wymiary:

a. silna obecność wizerunku (siła),

b. długie trwanie wizerunku (długotrwałość).

Przez silną obecność rozumiemy taką obecność wizerunku, która opiera się na obecności maksymalnie usilnionych parametrów (np. wielkość, intensywność, kolor, waga, zapach, etc.) stosowanych przez komunikatorów w wytwarzaniu danego wizerunku. $\mathrm{Z}$ kolei przez długie trwanie wizerunku rozumiemy taką obecność danego wizerunku, która opiera się na przedłużonym wymiarze czasowym tej obecności, zarówno w odniesieniu do pojedynczych egzemplarzy jednostek wizerunkowych (np. pojedynczych ludzi) jak i jednostek wizerunkowych o charakterze zbiorowym (np. gatunków biologicznych, instytucji, etc.). Stosowanie polityki wizerunku ma u człowieka szczególną 'przydatność adaptacyjną' (ang. adaptive fitness, zob. np. Gavrilets, 2004) nie tylko w bezpośrednich odniesieniach międzyosobowych/międzyinstytucjonalnych ale także w całokształcie bilansu istnienia człowieka jako gatunku na tle ogromnej różnorodności biosu.

\section{Ekonomia wizerunku}

Działalność wszelkich istot żywych podlega powszechnemu zjawisku ekonomii regulującemu ogólny i szczegółowy bilans tejże działalności. Ma on bezpośredni związek z odniesieniem sukcesu przez te istoty (poszczególne cielesności, zob. uwagi powyżej). Także wytwarzanie wizerunku i jego wymiana podlegają wszechobecnemu działaniu ekonomii, którą należy tutaj rozumieć jako wszelką działalność prowadzoną przez każdą istotę ożywioną (a w węższym kontekście człowieka, każdego transkomunikatora) zgodnie z zasadami ekonomii, przede wszystkim zasadą popytu i podaży. Działanie ekonomii jest jednocześnie organicznie związane z szeroko pojętą 'polityką wizerunku' istnienia każdego bytu ożywionego. Jak już powiedziano powyżej polityka ta wyraża się w dwóch prostych zasadach, a mianowicie: (1) zasadzie silnej obecności danej cielesności i (2) zasadzie długiego trwania tejże cielesności. W tym poszerzonym sensie ekonomia wizerunku nabiera dodatkowo charakteru 'ekonomii behawioralnej' (zob. np. Katona, 1975; Camerer i Loewenstein, 2003), czy w szczególnym przypadku człowieka nabiera charakteru 'ekonomii antropologicznej' (zob. np. Wilk, 1996; Gudeman, 2001; Carrier, 2005).

Stosowanie powyższych zasad jest ekonomicznie opłacalne dla każdego bytu jeśli prowadzi do odniesienia jednostkowego sukcesu. Dotyczy to także zjawiska generowania wizerunku i jego wymiany w obrębie wyżej wymienionego prawa powszechności wizerunku jako wypadkowej przytoczonych powyżej zasad polityki.

W odniesieniu do najbardziej interesującego nas tutaj konkretnego wymiaru człowieka jako transkomunikatora istota obecności i działania ekonomii w genero- 
waniu wizerunku wymaga świadomości i stosowania zasad ekonomii, przede wszystkim w najogólniejszym wymiarze makroekonomicznym, które mieszczą się w poczuciu komfortu wizerunkowego. Zatem makroekonomiczne działania wizerunkowe wynikają z dwóch podstawowych jego wymiarów, a mianowicie: (a) z posiadania wizerunku przez poszczególnych transkomunikatorów, rozumianego $\mathrm{w}$ sensie posiadania przez tychże zindywidualizowanego 'kapitału świadomościowego' rozłożonego na poszczególne części składowe wizerunku, czy to $\mathrm{w}$ odniesieniu do porządków komunikacyjnych, w których odbywa się komunikacja (zob. np. Puppel, 2015) czy w odniesieniu do innych dodatkowych parametrów im towarzyszących (byłby to składnik makroekonomii określony jako 'jakość-ilość' w czysto statycznym pojmowaniu wizerunku), oraz (b) z posiadania wizerunku rozumianego $\mathrm{w}$ sensie umiejętności generowania/inwestowania tegoż $\mathrm{z}$ racjonalną intencją maksymalizacji zysków w zmiennych warunkach środowiskowych, czyli zmiennych kontekstach komunikacyjnych (byłby to z kolei składnik makroekonomii określony jako 'płynność kapitału świadomościowego', a więc w czysto dynamicznym pojmowaniu wizerunku, zob. np. Leijonhufvud, 1979; Taylor and Woodford, 1999).

Nie ulega najmniejszej wątpliwości, że w wymiarze społeczno-kulturowym zarówno wymóg zrealizowania skuteczności wizerunkowej jak i połączony z nim wymóg odniesienia ostatecznego sukcesu wizerunkowego w szerszym działaniu o charakterze zabezpieczenia dobrobytu/dobrostanu wymagają od transkomunikatora synergicznego zastosowania obydwu podstawowych wymiarów makroekonomii, tj. kapitału świadomościowego i jego wielokontekstowej płynności w całym procesie zarządzania wizerunkiem obejmującym zarówno jego wytwarzanie jak i jego konserwację. Działania ekonomiczne w generowaniu, utrzymywaniu i konserwacji wizerunku przebiegają zatem według wymogów, które można ostatecznie określić w prawie olimpijskiej formule: więcej, dłużej, mocniej, piękniej.

\section{Wnioski}

Przedstawiony powyżej krótki, z konieczności zatem skrótowy, zarys teorii wizerunku w komunikacji człowieka pozwala na przedstawienie następujących głównych wniosków:

(a) Wizerunek jest zjawiskiem, które ma charakter powszechny w przyrodzie (biosferze). Jako takie jest z natury swojej semiotycznie izomorficzne.

(b) U człowieka wizerunek wynika nie tylko z naturalnych (biologicznych) właściwości gatunkowych $\mathrm{z}$ jednej strony mieszczących człowieka $\mathrm{w}$ różnorodności biosfery, ale także z dodatkowych uwarunkowań społeczno-kulturowych nakładających na wizerunek i działania około wizerunkowe, tj., jego generowanie, utrzymywanie (pielęgnację) i wymianę, szczególną przydatność społeczno-kulturową. 
(c) Uwarunkowania te nakazują generowanie i nieustanne utrzymywanie (pielęgnację) korzystnego wizerunku celem odniesienia przez transkomunikatora sukcesu komunikacyjnego w mniej lub bardziej otwartej przestrzeni publicznej.

(d) Określona atrakcyjność wizerunkowa jest u człowieka częścią większego układu obejmującego dobrostan człowieka jako gatunku jak i w wymiarze jednostkowym (także w wymiarze jego psycho-fizycznych atrybutów).

(e) Wizerunkowy sukces komunikacyjny człowieka jako transkomunikatora poprzez wszelkie działania około wizerunkowe, tj. generowanie, utrzymywanie (pielęgnację), ochronę (także korektę) i nieustanne wysyłanie korzystnego wizerunku w otwartej przestrzeni publicznej, ma szeroki i wielowymiarowy charakter psychologiczno-kulturowo-ekonomiczny. W konsekwencji wymaga odniesienia do świadomości odnośnie własnego kapitału świadomościowego i jego jakości jak i świadomości odnośnie istnienia różnorodności środowiskowej, czyli odniesienia do wszelakich kontekstów komunikacyjnych determinujących tzw. płynność w generowaniu poszczególnych odmian wizerunkowych jak i w wyborze poszczególnych strategii wizerunkowych w obrębie powszechnego, tj. dostępnego każdemu transkomunikatorowi, kompleksu wizerunkowego wespół z agregatem strategii wizerunkowych.

(f) W ten sposób transkomunikator jako ów mityczny Hefajstos, mając do dyspozycji zarówno swoją cielesność jak i zgromadzone przez siebie wielowymiarowe zasoby świadomościowo-językowo-kulturowe, niejako 'wykuwa' swój w miarę reputacyjnie jak najkorzystniejszy wizerunek na potrzeby nie tylko własnej (indywidualnej/gatunkowej) i w miarę korzystnej identyfikacji ale także jako wyraz przynależności do swojej kultury lokalnej i wspólnoty językowo-komunikacyjnej. Czyni to w następującej ogólnej formule: więcej, dłużej, mocniej, piękniej.

(g) Tak więc wizerunek jawi się ostatecznie jako z jednej strony wysoce ulotne (tj. nieustannie zmienne) narzędzie prezentacyjno-mediacyjne człowieka jako transkomunikatora, $\mathrm{z}$ drugiej zaś jako narzędzie umiejscowione i nieustannie dostępne wszystkim uczestnikom otwartej przestrzeni publicznej. Jest on 'zanurzony w morzu' wszystkich możliwych do zrealizowania wizerunków, które wypełniają tę przestrzeń i które niejako przepływają pomiędzy transkomunikatorami w nieustającym procesie ich wymiany.

\section{Bibliografia}

Archetti, M. 2000. "The origin of autumn colours by coevolution". Journal of Theoretical Biology 205. 625-630.

Archetti, M. i S.P. Brown. 2004. "The coevolution theory of autumn colours". Proceedings of the Royal Society of London B 03pb1147.1 
Ash, M.G. 1995. Gestalt psychology in German culture 1890-1967: Holism and the quest for objectivity. Cambridge: Cambridge University Press.

Attenborough, D. 1995. The private life of plants: a natural history of plant behavior. London: BBC Press.

Baron-Cohen, S., Tager-Flusberg, H. i M.V. Lombardo. (red.). 1993/2013. Understanding other minds: perspectives from developmental social neuroscience. Oxford: Oxford University Press.

Benjamins, W. 2008. The work of art in the age of its technological reproducibility, and other writings on media. Cambridge, Mass.: The Belknap Press of Harvard University Press.

Bloch, E. 2006. Traces. Stanford: Stanford University Press.

Camerer, C.F. i G. Loewenstein. 2003. "Behavioral economics: past, present, future". W zbiorze: Camerer, C.F., Loewenstein, G. i R. Matthew. (eds.). Advances in behavioral economics. New York and Princeton: Russell Sage Foundation Press and Princeton University Press. 3-51.

Carrier, J.G. (red.). 2005. A handbook of economic anthropology. Cheltenham, UK: Edward Elgar.

Chittka, L., Faruq, S., Skorupski, P. i A. Werner. 2014. "Colour constancy in insects". Journal of Comparative Physiology A 200. 435-448.

Connelly, B.L., Certo, S.T., Ireland, R.D. i C. Reutzel. 2011. "Signaling theory: a review and assessment". Journal of Management 37.1. 39-67.

Deleuze, G. 1994. Difference and repetition. New York: Columbia University Press.

Des Gasper. 2004. "Human well-being: concepts and conceptualizations". Discussion Paper No. 2004/06. United Nations University: World Institute for Development Economics Research.

Dyer, H. 2010. Watch this space: designing, defending and sharing public space. Toronto: Kids Can Press.

Ekman, P. 1997. "Lying and deception". W zbiorze: Ornstein, P.A., Stein, N.L., Tversky, B. i C. Brainerd. (red.). Memory for everyday and emotional events. Hillsdale, N.J.: Lawrence Erlbaum Associates. 333-347.

Gallagher, V.J., Martin, K.N. i M. Ma. 2011. "Visual wellbeing: intersections of rhetorical theory and design". Design Issues 27.2. 27-40.

Gavrilets, S. 2004. Fitness landscapes and the origin of species. Princeton: Princeton University Press.

Gintis, H., Smith, E.A. i S. Bowles. 2001. "Costly signaling and cooperation”. Journal of Theoretical Biology 213. 103-119.

Grimm, Jakub i Wilhelm. 2008. Najpiękniejsze baśnie. Warszawa: PWN.

Gudeman, S. 2001. The anthropology of economy. Malden, Mass.: Blackwell.

Guilford, T. i M.S. Dawkins. 1993. "Receiver psychology and the evolution of animal signals". Animal Behavior 42. 1-14.

Katona, G. 1975. Psychological economics. New York: Elsevier.

Komárek, S. 2003. Mimicry, aposematism, and related phenomena: mimetism in nature and the history of its study. München: Lincom.

Leatherbarrow, D. 1985. Janus and idea of the façade. Charlottesville, VA: Philosophy Documentation Center.

Lefebvre, H. 1991. The production of space. Oxford: Blackwell.

Leijonhufvud, A. 1979. The Wicksell connection: variations on a theme. Los Angeles: UCLA, Department of Economics.

Li, Xiuhui i Quinan Wang. 2007. "Coordination mechanisms of supply chain systems”. European Journal of Operational Research 179.1. 1-16.

Lidwell, W., Holden, K. i J. Butler. 2003. Universal principles of design. Beverley, Mass.: Rockport Publishers.

Maynard Smith, J. i D. Harper. 2003. Animal signals. Oxford: Oxford University Press.

Merleau-Ponty, M. 1945/1962. Phenomenology of perception. London: Routledge and Kegan Paul.

Mondzain, M.J. 2004. Image, icon, economy: the Byzantine origins of the contemporary imaginary. Stanford: Stanford University Press. 
Parrish, A.C. 2014. Adaptive rhetoric: evolution, culture, and the art of persuasion. London: Routledge.

Pentland, A. 2008. Honest signals. Cambridge, Mass.: The MIT Press.

Pike, K.L. 1957. "A stereoscopic window on the world (language and life, part 1)". Bibliotheca Sacra 114. 141-156.

Pike, K.L. 1967. Language in relation to a unified theory of the structure of human behavior. The Hague: Mouton.

Poulton, E.B. 1890. The colours of animals, their meaning and use, especially considered in the case of insects. London: Kegan Paul.

Puppel, S. 2009. "Remarks on the sustainability of natural languages in the cultural-institutional perspective". W zbiorze: Puppel, S. i M. Bogusławska-Tafelska. (red.). New pathways in linguistics. Vol. 2. Olsztyn: Uniwersytet Warmińsko-Mazurski. 275-286.

Puppel, S. 2012. „Zarys asonansowego modelu piękna w komunikacji ludzkiej”. Scripta Neophilologica Posnaniensia XII. 17-22.

Puppel, S. 2014. „Komunikator ustny jako performer właściwie ułożony i właściwie licencjonowany w przestrzeni publicznej”. Studia Rossica Posnaniensia XXXIX. 315-321.

Puppel, S. 2015. „Język w podmuchu, posiewie i przepływie: uwagi w sprawie synergii porządków komunikacyjnych w kontekście ekoglottodydaktyki”. W zbiorze: Puppel, S. (red.). MOTEK. Motywy ekolingwistyczne: w strone ekoglottodydaktyki. Poznań: Katedra Ekokomunikacji UAM. 143-150.

Puppel, S. 2016. "The politics of performativity in transcommunication and its communicative/expressive fitness: towards a general outline'. Scripta Neophilologica Posnaniensia XVI.

Reddy, V., Williams, E., Costantini, C. i B. Lan. 2010. "Engaging with the self: mirror behavior in autism, Down syndrome and typical development". Autism 14.5. 531-546.

Ruxton, G.D., Sherratt, T.N. i M.P. Speed. 2004. Avoiding attack: the evolutionary ecology of crypsis, warning signals and mimicry. Oxford: Oxford University Press.

Searcy, W.A. i S. Nowicki. 2005. The evolution of animal communication: reliability and deception in signaling systems. Princeton, NJ: Princeton University Press.

Siebeck, U.E. 2004. "Communication in coral reef fish: the role of ultraviolet colour patterns in damselfish territorial behaviour". Animal Behaviour 68. 273-282.

Speed, M.P., Brockhurst, M.A. i G.D. Ruxton. 2010. "The dual benefits of aposematism: predator avoidance and enhanced resources collection". Evolution 64.6. 1622-1633.

Steadman, P. 2008. The evolution of design: biological analogy in architecture and the applied arts. London: Routledge.

Taylor, J.B. i M. Woodford. 1999. Handbook of macroeconomics. Amsterdam: Elsevier/North Holland.

Trivers, R.L. 1971. "The evolution of reciprocal altruism". Quarterly Review of Biology 46. 35-57.

Van Lange, P.A.M. i A. Semin-Goosens. 1998. "The boundaries of reciprocal cooperation". European Journal of Social Psychology 28. 847-854.

von Uexküll, J. 1909. Umwelt und Innenwelt der Tiere. Berlin: J. Springer.

von Uexküll, J. 1926. Theoretical biology. London: Kegan,Paul, Trench, Trübner and Co.

von Uexküll, J. 2010. A foray into the worlds of animals and humans: with a theory of meaning. Minneapolis: University of Minnesota Press.

Wilk, R. 1996. Economies and cultures: foundations of economic anthropology. Boulder, CO: Westview Press.

Zahavi, A. 1975. "Mate selection: a selection for a handicap". Journal of Theoretical Biology 53.1. 205-214.

Zahavi, A. 1977. "The cost of honesty (further remarks on the handicap principle)". Journal of Theoretical Biology 67.3. 603-605.

Zahavi, A. 1997. The handicap principle: a missing piece of Darwin's puzzle. Oxford: Oxford University Press.

Zahavi, D. 2014. Self and other: exploring subjectivity, empathy and shame. Oxford: Oxford University Press. 


\section{Podstawowe pojęcia}

Adaptacyjny potencjał retoryczny Agregat strategii wizerunkowych Aparycja (Wygląd, Ogląd)

Architektura wizerunku

Atrakcyjność wizerunkowa

Dobrobyt/dobrostan

Dynamika wizerunku

Ekonomia behawioralna

Ekonomia wizerunkowa

Fasada o wysokiej efektywności

Globalny układ wizerunkowy

Jednostka wizerunkowa

Kapitał świadomościowy

Komfort wizerunkowy

Kompleks wizerunkowy człowieka

Otwarta przestrzeń publiczna

Płynność kapitału świadomościowego

Podaż

Pokaz

Polityka wizerunkowa

Popyt

Postaciowość ludzka
Prawo powszechności wizerunku

Przestrzenna architektonika

Przydatność adaptacyjna wizerunku

Psychologia wyglądu-oglądu

Samoprezentacja

Skuteczność wizerunkowa

Statyka wizerunku

Strategia wizerunkowa

Sygnalizowanie uczciwe

Sygnalizowanie zwodnicze

Transkomunikator

Uniwersalny mechanizm wykonawczy

Wizerunek jako narzędzie prezentacyjnomediacyjne

Wizerunek jako zjawisko semiotycznie izomorficzne

Wizerunkowe strategie modalnościowe

Wizerunkowe strategie postaciowe

Wizerunkowy sukces komunikacyjny

Wzorzec kombinacyjny strategii wizerunkowych

Zarządzanie wizerunkiem 